\title{
A BITTER BREW: COFFEE AND LABOR IN JAPANESE BRAZILIAN IMMIGRANT LITERATURE ${ }^{1}$
}

Seth Jacobowitz ${ }^{2}$

\begin{abstract}
Transoceanic passage brought nearly 189,000 immigrants from Japan to Brazil between 1908 and 1941. They were often geographically isolated in Japanese "colonies" as coffee plantation workers and thus able to maintain their Japanese linguistic and cultural identity. A new imagined community coalesced in the several Japanese-language immigrant newspapers that also published locally produced serial fiction. This paper reads two representative works by Sugi Takeo, pen name of Takei Makoto (1909-2011), who was a prolific contributor of original content to the Burajiru Jihô newspaper. In the short stories, "Kafé-en o uru" (Selling the coffee plantation, 1933) and "Tera Roshya" (Terra rossa, 1937), it is the moonshine sellers who see steady profits from every race and type of immigrant laborer while the Japanese newcomers who naively dream of riches by bringing coffee to market reap only a bitter brew of poverty for their efforts.
\end{abstract}

Keywords: Nikkei, Immigration, Literature, Transnational, Coffee

\section{Introduction}

Prohibited from entering Australia, discriminated against in the United States, persecuted in Canada, and limited even from entering Hawaii and the Pacific Islands, our workers will find in the state of São Paulo a rare felicity, a veritable paradise. — Sugimura Fukashi, Japan's plenipotentiary minister to Brazil (1906) ${ }^{3}$

1 Article received and accepted in 2019.

2 Assistant Professor, Yale University, Department of East Asian Languages \& Literatures, New Haven, Connecticut, United States; Ph.D., Cornell University; seth.jacobowitz@yale.edu (ORCID iD https:// orcid.org/0000-0002-4172-5046).

3 Saitô Hiroshi, O Japonês no Brasil: estudo de mobilidade e fixação. São Paulo: Fundação Escola de Sociologia e Política de São Paulo; Editora Sociologia e Política, 29. Also quoted in Marcia Yumi Takeuchi, "Os japoneses e as árvores dos frutos de ouro," in Maria Luiza Tucci Carneiro, ed., São Paulo: Metropolis das Utopias, 255. All translations from Japanese and Portuguese to English are my own unless otherwise noted. 
In the period from 1908 until 1941, an estimated 189,000 Japanese emigrated to Brazil to seek their fortunes in the booming coffee plantations of the state of São Paulo and neighboring regions. ${ }^{4}$ As the above quote from Japan's plenipotentiary minister to Brazil affirms, in the face of rampant discrimination throughout the Anglophone world, the Empire of Japan found a willing partner to accept its so-called "surplus population" (kajô jinkô) in what was then the Republic of the United States of Brazil (1889-1930), which desperately needed immigrants for plantation labor and to develop the interior of the country following the abolition of slavery in 1888 . The influx of Japanese alongside several million South and Central European immigrants during this same period was encouraged by the politically powerful planter class in the State of São Paulo with the immense profits of the coffee industry to back it up. The success of Japanese mass migration was such that in spite of a myriad of other crises-World War I, the Great Kantô Earthquake, The Great Depression, the Manchurian Incident, and so on - the vast majority of the immigrants, or just over 160,000, settled in Brazil in the two decades between 1921 and 1941. The mixed sentiments toward the Japanese consistent with Yellow Peril fears elsewhere notwithstanding, it was only in the late 1930s when repressive measures designed to Brazilianize the population were brought by the Vargas administration. Immigration was halted altogether in 1941 after Pearl Harbor, to be followed by Brazil's formal declaration of war against Japan in August 1942. Immigration only resumed in 1952 after the Empire of Japan had ceased to exist.

The immigrants mostly came from poor, rural regions disenfranchised by an uneven modernization that concentrated resources in Japan's major metropolises, industrial heartland, and burgeoning empire in Northeast Asia. They were urged to emigrate as the patriotic duty of imperial subjects coupled with ready assurances of a better life in a tropical climate with vast expanses of arable virgin land. Although economic opportunity was overwhelmingly the primary motive for the majority of immigrants, other contributing factors included avoiding ruinous taxation and losing sons to Japan's incessant wars. Okinawans perhaps unsurprisingly constituted the single largest bloc by prefecture. The descendants of hidden Christians from Kyûshû were amongst the first to emigrate and would be re-united in Brazil with the Catholic

4 The official number of 188,986 Japanese immigrants to Brazil from 1908 to 1941 is cited in Teiiti Suzuki, ed., The Japanese Immigrant in Brazil (Tokyo U. Press, 1964), 14-16. However, as noted by Mori Kôichi et al., eds., Burajiru Nihon imin hyakunenshi, vol. 1 (São Paulo: Toppan Press, 2012), "there is a slight variation between the Japanese and Brazilian governments' immigration statistics, as well discrepancies that arise in the immigration histories published by the Nikkei community. For instance, in Imin nanajûnenshi, the number of prewar immigrants is given as 196,737, whereas in Imin hachijûnenshi the number compiled from the records of each immigrant community added up to 181,065. In Nihonjin hattenshi it is 183,518, while according to the 'Hakkoku rôdô shôkôshô imin kyoku' the figure is given as 188,309 " (footnote 3,38 ). Needless to say, this number does not include their Brazilian-born (Nisei) children, which puts the total population in Brazil well over 200,000 by the onset of WWII. 
Church from which their ancestors had been sundered nearly 300 years earlier. A substantial number came from Hokkaido in a pattern of frontier settlement and expansion that would be repeated time and again in the era of colonial migration and expansionism. ${ }^{5}$ Yet above all, the simple fact remained that wages outside Japan were higher whether the destination was in North or South America. The protagonists of Henry Yoshitaka Kiyama's Manga yonin shosei (The four immigrants, 1931), ${ }^{6}$ based on four actual sojourners, were among the estimated 140,000 to arrive in the United States prior to the Gentlemen's Agreement. These young men happily wash dishes and peel potatoes as houseboys in San Francisco, safe in the knowledge they are earning more than the clerks in city hall back home.

The Japanese in Brazil, by contrast, were often geographically isolated in farming communities and coffee plantations, and thus able to maintain a high degree of linguistic and cultural autonomy, despite being "like drops of water into a bucket" who disappeared into the continental vastness of the country, as Ishikawa Tatsuzô wrote in his novel Sôbô (The emigrants, 1935), which received the first Akutagawa Prize for Literature in recognition of Brazil's importance to Japanese expansionism at the height of the empire. Although literary scholars regard its theme of overseas migration to Brazil as something of an outlier in the modern Japanese canon, in fact a considerable body of popular immigrant literature was published in Japan from 1908 into the 1940s in the pro-expansionist journals Shokumin Sekai (Colonization World), Burajiru (Brazil), Kaigai (The Overseas Journal), and Shokumin (The Colonial Review) that demand serious scholarly attention. These works were published alongside articles that valorized the heroic immigrants fanning out around the world to represent an expansionist Japanese race and empire. In turn these texts contributed to a corpus of shared knowledge between empire planners, pro-expansionist organizations such as the Nippon Rikkôkai, readers at home, and immigrant who took the plunge overseas.

The 781 immigrants who made the inaugural voyage on the Kasato Maru from Kobe to Santos in 1908 brought with them the habitus of a Japanese-language press and literature. Thereafter newspapers would be regularly produced during the fifty-day transoceanic voyage before the immigrants even set foot in their adopted land, with poetry and prose expressing their aspirations for the future as well as longing for their homeland. Akin to their counterparts in Hawai'i and California, they once again set about reproducing the main aspects of Japanese print culture in accordance with their new circumstances. The earliest Japanese-language newspapers and journals in Brazil began with handwritten and mimeographed copies, scaling up as the population surged in the two decades before WWII. Four newspapers - the Burajiru Jihô, Nippak

5 See for instance Sidney Xu Lu, "Colonizing Hokkaido and the Origin of Japanese Trans-Pacific Expansion, 1869-1894,” Japanese Studies 36:2 (2016): 251-274.

6 The book was self-published by Kiyama in San Francisco in 1931 after unsuccessful attempts to have it serialized in a Japanese language newspaper. It was rediscovered and translated by Frederick Schodt under the title The Four Immigrants Manga (Stonebridge Press, 1999). 
Shimbun, Seishû Shimpô, and Nambei Shimpô-were published in the city of São Paulo over the thirty-three year period. Only about three percent of the Japanese population actually resided in the city of São Paulo before 1941, with the majority loosely spread out on coffee plantations and agrarian communities in the interior of the state. Colonies were also established as far away as Pernambuco, Pará, and Amazonas, for whom the newspapers proved a valuable lifeline to their countrymen and women.

Locally written works appeared from the very beginnings of the Japanese presence in Brazil. However rudimentary, publications whose ostensible purpose was to impart practical knowledge such as the mid-1920s magazine Nôka no tomo (Portuguese title: Amigo dos lavradores; lit., The farmer's friend), included poetry and short fiction in their back pages, in direct emulation of the pattern set by Japan's national magazine culture. Homegrown literature was essential for shaping and reflecting upon what it meant to be Japanese in Brazil, indeed, to be Japanese in the world, at this time. Amongst the four principal newspapers, the Burajiru Jihô (Portuguese title: Notícias do Brasil) arguably did the most to support literary narratives of a transplanted Japanese language, culture, and people through locally produced serialized fiction. Backed by the largest Japanese emigration company, the Kaigai Kôgyô Kabushiki Kaisha (KKKK), it was equipped with the best printing equipment, as well as an editor, Kuroishi Seisaku, who had been recruited from San Francisco.

In contrast to the world events and national news from Japan and Brazil that graced the front pages, these literary texts by and for the immigrants offered an unvarnished take on the hardships they faced. Benedict Anderson's thesis about the simultaneity of national subjectivity maintained through newspaper and novel takes on heightened significance in the Japanese Brazilian context, where narrative prose fiction above all was integral for preserving bonds of continuity amongst readers in Brazil as well as from the homeland. The corpus of writing by and for the immigrants offered further spiritual and emotional sustenance that mainstream periodicals and books imported from Japan did not. ${ }^{7}$ At the same time, we must be attuned to the constant demands for adaptation and acculturation already underway before the Brazilian state intervened and ultimately shut down the press and nascent prewar Japanese Brazilian literary scene.

It is with this context in mind that I introduce two short stories by Sugi Takeo, pen name of Takei Makoto (1909-2011), that were serialized in the Burajiru Jiho in the 1930s. Sugi was a prolific amateur writer and critic who prescriptively called for a new "colonial literature" (shokumin bungaku) that affirmed imperial subjectivity, but was reflective of the particular characteristics of the Brazilian immigrant experience. I seek to trace the ways Sugi negotiated the ambiguities, social ills, and hardships for the

7 For a useful overview in English of Japanese-Brazilian print culture as well as valuable analysis of both the semantic and historical origins of Japanese-Brazilian colonial literature, see also Edward Mack, "Paracolonial Literature: Japanese-language Literature in Brazil," Ilbon yŏn'gu 16 (2011): 89-128. 
Japanese laborers far removed from the prosperity they had been promised would come with hardwork. This included his keen observations of racial discrimination against, but also within, the Japanese community that expose the uneasy social structures and assemblages of colônia life.

In "Kafé-en o uru" (Selling the coffee plantation, 1933) a Japanese family is forced to sell their land at a total loss exacerbated by the predations of soldiers from the Constitutionalist Revolution of 1932, also known as the Brazilian Civil War. It is one of perhaps only two works in modern Japanese literature (the other, "Seishi Gika," having been written by Ishikawa and serialized in the journal Shokumin), for its portrayal of the repercussions against the Japanese immigrants as a result of the coup d'état that brought Getulio Vargas to power in 1930 and the ill-fated Paulista rebellion two years later. Moreover, Sugi's literary corpus firmly plants Japanese literature in Brazilian soil such as in "Tera Roshya" (Terra rossa, 1937), ${ }^{8}$ which derives its title from the red clay soil that established the State of São Paulo as king of the global coffee trade. Sugi is unsparing in representing the risks and setbacks that came with the cultivation of coffee, from market forces to the mercilessness of nature. Amidst these myriad forces outside their control, it is ironically moonshine sellers in both stories who see steady profits from every race and type of immigrant laborer. The Japanese newcomers who naively dream of riches by bringing coffee to the market, meanwhile, reap only a bitter brew of poverty for their efforts.

2. Despite the dramatic growth and maturation of scholarship on Japanese imperialism in East Asia in recent decades, the history and literature of Japanese immigration to South America has with a few significant exceptions been severely overlooked. I follow Eiichirô Azuma's argument that immigration was an indispensable pillar of expansionism alongside imperialism, as well as his critique that scholars in Asian Studies and Asian American Studies often treat immigration and imperialist expansion as separate and mutually exclusive fields, despite the fact these discourses were in fact intricately linked in Japan for three-quarters of a century. As Azuma contends:

Instead of simply creating the infrastructure of imperial rule within Japan proper, they [advocates of Japanese expansion] argued that the country should embark on a project of real empire building through mass emigration, international trade, and, if necessary, proactive military deployment. Because the emigration of rural people to Hawaii and the American West had just begun in the mid-1880s, nationalists willingly mistook the popular practice of temporary work abroad (dekasegi) for the first instance of Japanese colonialist expansion in the modern

8 Since Italian term "terra rossa" is used in English as a soil classification, I preserve its usage throughout. In Portuguese the correct spelling is terra roxa. 
era. Founded by the hard-liners in 1893, the Colonization Society (Shokumin kyôkai) reified such conceptual confusions because its members equated statesupported colonialist ventures in Asia and the Pacific with mass labor migration to the Americas (Shokumin kyôkai hôkoku 1893,102-18). While calling for an imperialist war, such pundits expressed a desire to see more and more subjects of their "expansive nation" migrating abroad for the "conquest of frontiers" and the building of "new Japans" beyond Japanese shores (Azuma 2000, 39-40). ${ }^{9}$

Azuma has in mind here specifically immigration to Hawai'i and the United States prior to 1907. Similar semantic and ideological conflations were to occur in Japan's mass migrations to Brazil and South America from 1908 onward. Immigration was already an indispensable feature of Japanese modernity since the 1880s not only for its capacity to reduce poverty and overpopulation, but also more importantly for the valuable remittances in hard currency sent home by immigrant labor. The phenomenon of dekasegi, or traveling from one's hometown to perform temporary contract labor was a normal part of the labor cycle in rural Japan ${ }^{10}$ and extended to working overseas in Australia, Hawai'i, California, the Pacific Northwest, Mexico, and Peru. A tapestry of coordination between public and private enterprises in Japan and Brazil arose to replace the flawed contract labor model. In addition, there were welldefined policies backing up efforts to keep immigrants to Brazil linguistically, culturally, and nationalistically, within the fold (or folk) of the Empire. For their part, the Brazilian authorities sought to break the dekasegi practice by requiring the Japanese to emigrate as families. In this sense it is more correct to say 165 families arrived on the Kasato Maru than 781 individuals. The insistence upon the family unit was not only for the ostensible purpose of stabilizing a population that might otherwise consist solely of single men, but to flood the labor market with cheap labor and create a more permanent and self- perpetuating labor pool. Needless to say, those who were desperate to leave Japan often formed spurious families for the purpose of satisfying the requirement, and often dissolved these relationships upon arrival in Brazil.

If I have until now rigorously referred to the Japanese population as immigrants, it is important to remember that the term Nikkei (or Nikkey in Portuguese) to denote those of Japanese heritage did not exist in the prewar. The Japanese referred to themselves as Nihonjin/Hôjin (Japanese), or (kaigai/zaipaku) dôhô, meaning (overseas/Brazilian resident) brethren. They also used the Portuguese terms colono and colônia (colonist and colony) respectively for the agricultural workers and

9 Eiichirô Azuma, "'Pioneers of Overseas Japanese Development': Japanese American History and the Making of Expansionist Orthodoxy in Imperial Japan," The Journal of Asian Studies, vol. 67, No. 4 (November 2008): 1193.

10 Wakatsuki Yasuo. “Japanese Emigration to the United States, 1866-1924: A Monograph.” Perspectives in American History 12 (1979): 447. 
communities. By the same token, although the Japanese referred to themselves in their native tongue as imin (immigrants), it was equally common for them to selfreferentially employ the terms shokumin (colonists), kaitakusha (settlers), senkusha (pioneers) and so on, consistent with the vision of extending the imperial mission as overseas Japanese. Nikkei only came into existence in the postwar period following the collapse of the empire and loss of sovereign claims over all immigrant and colonial peoples. In the prewar era, while questions of national belonging and subjectivity remained powerfully conditioned by one's generational proximity to Japan (i.e., Issei, Nisei, and even Jun Issei, the so-called 1.5 generation born in Japan, but raised overseas), this, too, affirmed one's status as a subject of Japan. According to Ishikawa Tatsuzô's firsthand account Saikin Nanbei ôraiki (A record of recent travels in South America) published four years prior to Sôbô, by the mid-1920s, the "Brazil rush" (Burajiru rasshu) ${ }^{11}$ led about ten thousand Japanese per year to board ships bound for South America in the Twenties, which more than doubled in the first half of the Thirties. Upon departing Kobe, the immigrants experienced a melancholic feeling of the immigrants that in Portuguese would be called saudades. It prompted Ishikawa to articulate several different affective responses. "Good-bye my motherland!" he writes in English, although it is not precisely clear to whom or for whom this sentiment is expressed. ${ }^{12} \mathrm{He}$ further describes the immigrants as unwittingly taking part in a larger series of global movements: "With the rotational speed of Japanese civilization increasing day by day, its uncontrolled centrifugal force expels countless numbers including this one thousand people" on his ship. ${ }^{13}$ Lauded by Ishikawa, furthermore, as "pioneers of overseas development" (kaigai hatten no senkusha), the immigrants have reasons for leaving the motherland which he ascribes to "painful changes in the social structure" (shakai soshiki kaihen) in Japan proper. ${ }^{14}$ Unable to find suitable work in their hometowns, factories, or in Japan's urban economies buffeted by cyclical crises, they had no choice but to try their luck abroad as "exiles" (kimin).

Notwithstanding the fact that the Japanese in Brazil proved exceptionally resourceful agriculturalists and horticulturalists, the most common source of employment was on the coffee-plantations in Sao Paulo and neighboring state of Paraná. Unsurprisingly, the majority were to discover the "new paradise" (shin tenchi) of endless tropical farmland promised by the information campaigns and propaganda distributed in Japan did not live up to those lofty heights. In an entry dated May 5, 1929 in Saikin Nanbei oraiki, Ishikawa observes that Brazil was already in recession, even though the onset of the Great Depression with the market crash of October 1929 was still nearly six months

\footnotetext{
11 Saikin Nanbei ôraiki, 12.

12 Ibid., 12.

13 Ibid., 13.

14 Ibid., 13.
} 
away. ${ }^{15}$ Brazil's woes were caused by a surplus of coffee on the market and Ishikawa was absolutely correct that the problem was entrenched. The only solution was a forcible reduction in the supply. As an article in the June 12, 1932 New York Times reported, "Brazil's program of destruction of coffee to support the price of that commodity in all markets has now been in force exactly one year. In that time 7,103,000 bags of coffee beans have been burned or otherwise destroyed. They were valued at approximately $\$ 30,000,000 . " 16$ And yet the largest number of immigrants, 72,661 individuals, surged between 1931 and 1935 while this price stabilization was taking place.

3. There is a widespread misconception that because the Japanese Brazilian immigrants were overwhelmingly poor farmers, they were therefore subalterns denied the ability to speak on their own behalf. The immigrants led generally arduous lives, but they provide every indication of having eagerly contributed to, and consumed, homegrown fiction, poetry, essays, film reviews, and so on. Although there were a few long-running serializations of samurai tales and detective fiction as well as the occasional belles lettristic work from Tokyo reproduced in the pages of the newspapers,${ }^{17}$ the literary columns were by design intensely local in focus. This included articles by Sugi and others calling for the evolution of a colonial Japanese literature true to their lives in South America. Sugi emerges as a leading light on both the literary and critical fronts: he published no fewer than seven works of fiction and was outspoken in his desire to see not only a greater maturity of stylistic expression style, but also a greater depth of ideological commitment to the plight of immigrant labor by his contemporaries.

The Burajiru Jiho nurtured this nascent Japanese literary scene by creating the Shokumin Bungei Tanpen Shôsetsu-shô, or Colonial Literature Short Story Prize in 1932, one year shy of the twenty-fifth anniversary in Brazil. Fiction writers tended to be better educated and occupied more privileged positions than the average farm worker. Sonobe Takeo (biography unknown), winner of the inaugural first prize in 1932, admitted he'd been in Brazil for seven months without ever setting foot on a coffee plantation when he wrote his avant-gardist masterpiece set in the city of São Paulo, "Tôbakuno jidai" (In the age of speculative farming). The runner-up for that year, Nishioka Kunio's (pseudonym of Tanabe Shigeyuki) "Aru kaitakusha no shi" (Death of a certain settler) likewise has little to say about coffee in its portrayal of the murderous confrontation between a cruel Japanese landowner and itinerant black laborer.

Sugi Takeo was born in Hokkaido in 1909 and educated in the Teacher's Division of Hôsei University in Tokyo before emigrating to Brazil in 1932. He

15 Ibid., 84.

16 Author unnamed, June 12, 1932 issue of New York Times.

17 Mack, 108-109. 
worked for a time as a Japanese language teacher and bookstore owner in the town of Lins, although he was to lose his means of earning a livelihood when the Brazilian government banned the teaching and publication of Japanese. Sugi's work consistently represents settlers, colonists, and pioneers in the remote interior of Brazil. Written as a collection of vignettes, they are nevertheless complex representations of a Japanese Brazilian state of being in the world. If he was perhaps not "salt of the earth," his workmanlike prose is nevertheless rooted in quotidian coffee plantation life, and therefore represents the immigrant experience as Sonobe, Nishioka, and others do not. Likewise, in spite of his status as an inveterate also-ran in the prize competition, he continued to see his work published, whereas others such as Sonobe and Nishioka vanished from the scene after 1932 as one-hit wonders. Sugi's short stories in the Burajiru Jihô include "Michiko no shi" (Michiko’s death, 1932), "Kafé-en o uru" (1933), "Ensoku” (The excursion, 1934), and "Terra Roshiya" (1937), none of which won the first place prize.

According to Nikkey Shimbun cultural critic Arata Sumu, Sugi shifted his publishing efforts toward the promising, but short-lived literary journal Chiheisen (Horizon). There he went on to publish one additional story, "Nusumi" ([Theft] 1936), in the inaugural issue and several essays such as "Ideorogî no mondai" [The question of ideology] in the sixth issue. However, the journal ceased publication with the ninth issue. ${ }^{18}$

Sugi's short story "Fukushû" (Revenge, 1938), originally published in Chiheisen, appeared in the Koronia shôsetsu senshû (Colônia short story anthology) vol. 1 (São Paulo: 1975), was republished by the Koronia Bungakkai (Colônia Literary Association). Intergenerational conflict and imperial masculinity is on full display. At a time when every able-bodied young man was needed to fight the Imperial Army's wars in East Asia, a young Japanese man's competition for a young woman's affections with an older rival becomes the pretext for the latter to challenge the former's loyalty to Japan. It is likely that such a work would be banned had Sugi been foolhardy enough to try to publish it in Japan. Such an option did not exist, but irrespective of a theoretical reception in Japan, it was ultimately the Brazilian authorities that enacted a sweeping prohibition of Japanese publications and effectively shut down what Arata justifiably calls the golden age of colonial Japanese literature. To the best of my knowledge it was the last story Sugi wrote. ${ }^{19}$

The first of four installments of an essay by Sugi entitled "Shokuminchi bungaku no kakuritsu" (The formation of colonial literature) was serialized in the Jan. 10,

18 Arata Sumu, "Takei Makoto-san o shinobu," Feb. 3, 2015 issue of Nikkey Shimbun. I have provided the English translations of the titles in brackets.

19 As Arata Sumu notes in the Feb. 4, 2015 third installment of "Takei Makoto o shinobu," while Sugi lived to be 102 and a half years old, he never again took up his pen after the hardships this inflicted forced him to seek another livelihood. The biographical sketch provided for him in the Koronia shôsetsu sensh $\hat{u}$, vol. 1, indicates that he worked in the 1970s for a pharmaceutical company based in São Paulo (55). 
1934 issue of the Burajiru Jihô. ${ }^{20}$ Sugi was quite unsparing in his criticism of the earlier works produced in Brazil, calling them little better than what could be found in the pages of dôjinshi, or magazines for the self-published work of amateurs. He called for writers in Brazil to develop greater literary skill, although his recommendations are rather vague. In the second installment he dismissed old-fashioned approaches to literature that might be found in the widely read magazines back in Japan, insisting "you're better off taking a mighty swing with an enchada (hoe) than to spend a solitary moment of time on a work devoid of expression or content."21

He continues his criticisms of "pure literature" (junbungei) that is now in decline against "popular literature" (taish û bungei). Pure literature, he avers, has lost touch with the people. The immigrants in Brazil have need for a literature that keeps pace with their own lives. Preaching with the energy of the newly converted, he emphasizes the Russia-like immensity of nature in their adopted country: "Both regionally and spiritually speaking, those of us in Brazil find ourselves in a special environment different from Japan. Our sentiments were born in the singular environment of Brazil's nature and colonies." For better or worse, he persists, the colonies are a place where fortunes are made and everyone hustles after money (kanemôke) ${ }^{22}$ Consequently one must reckon with that prevailing ethos as a writer. In the third installment he concedes it is only to be expected that works that did not pay attention to the defining characteristics of this colonial society were doomed to fail with readers. He singles out the short story "Natsuyo" which won the prize that year as a work that was not set in Brazil and therefore lacked any sense of connection to the readers' lived experiences. Instead it was just "something to read" (tan naru yomimono) but unworthy of serious literary consideration. ${ }^{23}$

20 It appears alongside a short, unfinished piece by prolific fellow writer, editor, and leader in the nascent literary scene, Furuno Kikuo (1907-1989), which argues one should not compare the mostly rural and laboring class of Japanese immigrants with the arrival of the English immigrants to North America, who belonged to the same historical era of the English language as Shakespeare.

21 Sugi, "Shokumin bungaku no kakuritsu," Jan. 19, 1932 issue of Burajiru Jihô.

22 Alongside the fourth installment of Sugi's "Shokuminchi bungaku no kakuritsu" in the Jan. 31, 1934 issue of the Burajiru Jihô is an article by Amago Hannosuke, "1933- nen no zaihaku Hôjin bungakkai o kaerimiru" (Looking back at the literature by the Japanese in Brazil in 1933). It, too, reflects on the state of literature at the twenty-fifth year anniversary mark. Echoing Sugi, Amago laments the materialism of the literature and immigrant community, whose principal aim is grasping after money. See also Mack's discussion of Sugi and other critics on the formative concept of colonial literature, 116-118.

23 Katayama Teruko (pseudonym of Hayashi Ise, born 1899), the author of "Natsuyo," was one of the few women to be published in the prewar era. Although the editors of the Koronia shôsetsu sensh $\hat{u}$, vol. 1 (1975) gave it a prominent place in the anthology right after "Tôbakuno no jidai" and "Aru kaitakusha no shi," Sugi's criticism holds true insofar as the story about a loyal Tokyo housewife's betrayal and decision to emigrate says nothing about the conventional reasons for overseas emigration or tribulations of daily life in Brazil for the newcomers. 
Sugi excitedly calls for the young writers in Brazil to "develop some kind of method for finding that hidden land" of superior literary works. In the fourth installment he makes a digression into talking about tanka, the short form Japanese verse, its reformists and practitioners in Brazil, considerably verging off topic. Yet in the final paragraph he brings the topic back around to prose fiction to closes with a bang: "In Korea haven't the Koreans made a colonial novel (Chôsenjin ni yoru shokuminchi shôsetsu ga dekita no de wa nai $\mathrm{ka}$ )? It's a shame that after twentyfive years the one hundred fifty thousand of us in Brazil have yet to see anything in our literary works until now, but perhaps in 1934 something new will come along." ${ }^{24} \mathrm{In}$ parsing this final provocative statement, it is difficult to know how Sugi arrived at this claim. One can only wonder what colonial Korean works he may have read or heard about prior to, or for that matter, after his arrival in 1932? Did Sugi have in mind the work of Japanese settlers and pioneers as overseas brethren or actual colonial Korean writers? We are once again confronted by the semiotic ambivalence inherent in the term "colonial literature." However inadequately this terse sentence lends itself to critical inquiry, it sets forth a clear correlation between the imperial mission in Korea and Brazil. It was a move often made in journals such as Kaigai and Shokumin that unified imperialism and immigration into a single seamless doctrine of expansionism.

Sugi's second major critical piece, "Shokumin bungaku ni tsuite" (On colonial literature), which was published in the Burajiru Jihô newspaper, Oct. 23, 1935, advocated for a new literature written by and for the Brazilian "colonists" that should surpass the disappointingly low level of the works written to date. Sugi interchangeably uses the terms colono and shokumin in his attempts to articulate a critical analysis of workers' exploitation that would appear to cut across national boundaries.

Therefore the attitude of authors who write colonial literature must describe the position of the colonos or colonists (shokuminsha) still laboring under the remnants of the colono or serf system (nôdôsei no zangai). For this reason we must study the social and economic structure of the colonies. To truly capture their reality we must understand how the social and economic structure of the colonies establishes the ideology of the colonos, of the colonists. ${ }^{25}$

Unlike the previous essay that he concluded by explicitly bridging the distance between Northeast Asia and South America, here he presents a critical agenda into that Marxist critics would call superstructure. This more nuanced approach seems consistent with his later literary efforts to represent and critique the systematic ways in which labor was still trapped on the land in conditions of servitude and poverty.

24 Sugi, "Shokumin bungaku no kakuritsu," Jan. 19, 1932 issue of Burajiru Jihô.

25 Sugi, "Shokumin bungaku ni tsuite" Oct. 23, 1935 issue of Burajiru Jihô. 
One might justifiably be forgiven for seeing in it an inchoate alignment with proletarian literature that nevertheless avoided calling it by name.

4. Serialized in ten installments beginning on Oct. 4, 1933, "Kafé-en o uru" tells the story of a newcomer Japanese family in their third year of cultivating their own coffee trees who are met with one misfortune after another. The father and head of the household is terminally ill, leaving his wife and eldest son, Kichizô, to tend to their business affairs. The story begins with an encounter at the remote farm between Kichizô and a soldier on a horse accompanied by a young woman on another horse also dressed in the uniform of a soldier. The man intimidates Kichizô and steals his horse's stirrups, cutting them off with his rusty, but sufficiently sharp sword. Kichizô's mother instructs him to hide the horse in the forest to avoid its being stolen, too. He is perplexed what drew the soldiers so far out into the hinterlands, but his mother provides the answer: the proximity of their farm to the stills where pinga is made. In any case, they cannot afford to lose this horse, which is not theirs, but belongs to the landholder Tanaka, and represents more than the entire fortune they possess outside the farm itself. But first his mother agrees to send him to Tanaka to sell their corn and pay the interest on their loans. She bitterly reflects on the fact that they haven't had a single good harvest in their three years in Brazil. This is one of several incidents in which Kichizô will attempt to stave off the inevitable loss of the family's coffee trees.

The first installment ends with Tanaka and his workers are busy making pinga, and in the conversation that ensues both he and Kichizo discuss their financial difficulties due to the "revolution" (kakumei), specifically referring to the Constitutionalist Revolution of 1932. Known also as the Paulista War and the Brazilian Civil War, it was fought by the state of Sao Paulo against the coup d'etat that delivered Getulio Vargas into power and ended the First Republic in 1930. The military conflict lasted only 87 days, from July 9 to October 4, 1932, but the instability it precipitated kept Vargas in the office of the president until 1945 and led to the establishment of the fascist-influenced, authoritarian regime of the Estado Novo in 1937. It is not immediately clear in the story which side the soldiers are on, or precisely when the story takes place - is it in the thick of the previous year's conflict or its aftermath? The ambiguity is perhaps a function of the narrative focus on a family far removed from a detailed awareness of what is transpiring in the country, as the mother does not speak "Brazilian" (Burajirugo) and Kichizô appears to have only a basic conversational ability.

In the second installment the soldiers are now making daily visits to Tanaka's farm to steal buckets of pinga. Tanaka suspects an argument with one of the camaradas (Brazilian day workers) led to his informing the soldiers of the pinga operation in revenge. The drunken soldiers are dangerous to both themselves and others-one falls off his horse, another steals chickens. But the real fear is that they will start stealing horses, which is precisely what happens to Kichizô. A soldier finally takes his 
horse, throwing him a milréis in recompense, an utter pittance. In the third installment his mother and father impotently scream at him that he should have carried a pistol, but the neighbor Aoki, upon hearing the story, expresses what the reader already knows: this would likely have cost Kichizô not only the horse, but his life. In the fourth installment he commiserates with others who've also been preyed upon, but there is nothing he can do to get the horse back or make up the money. In the fifth to eighth installment he tries to sell a pig (called porco in Portuguese, not buta as in Japanese) ${ }^{26}$ to raise some funds, but this too is unsuccessful. Curiously enough, despite the impending financial disaster the family faces, in the eighth installment Kichizô stops off with his little sister to the bakery and purchases some sweets for her and his mother. We are reminded what Ishikawa observed in Saikin Nanbei oraiki to the effect that while not everyone who works in Brazil strikes it rich, at least, unlike in Japan, they are in no danger of starvation.

By the same token, in the tenth episode Kichizô and his mother feed the dying father slices of orange grown on their own farm. Kichizô and his father talk about the frost that damaged their coffee trees the year before last, and will set back their profitability another three years (six in total), which the father will not live to see. This prompts the only dialog from the father, who sheds light on what brought the family to Brazil in the first place. "When I came from Japan I had big ideas," he tells his son,

I was just like the rest back in Japan dreaming of Brazil, convinced I'd instantly become a great success. I had no idea what it meant to be a farmer [hyakusho]. On the ship coming over I met a man whose name slips my mind, but he was from a farming family going way back. That's right, now I remember, his name was Shiraishi. One time I saw him laugh at his kids playing. I took a shine to him and we watched together. [...] "Kichi, Shiraishi couldn't so much as write his name, he didn't have a single lick of learning about him. But the rest of us couldn't hold a candle to him when it came to the depth of his experience as a farmer. He'd thought things through the right way. He had no illusions about Brazil. One time Shiraishi showed me a photograph of a coffee plantation. 'I'm going to plant rice,' he said. I was so obsessed with coffee, I couldn't believe my ears. 'Growing rice is the only thing I know how to do,' he said. [...] Since we arrived in Brazil, I realized I'd been dreaming about coffee and nothing but since I was twelve or thirteen years old. While the rest of us were clamoring about the cost per bag of coffee, only Shiraishi insisted that a farmer eats what he grows and sells what is left over. We were

26 The extensive incorporation of Portuguese nouns for farming equipment and everyday productsenchada, doce, porco, toma café, etc. attest to the changing nature of the Japanese language within the dominant Lusophone environment. See Mack, 113-114, as well as Zelideth Rivas' "Songs from the Land of Eternal Summer: Beyond Duality in Japanese Brazilian Publication and Colônia Man'yôshû," Comparative Literature Studies 52:4 (2015): 799-801, on linguistic hybridity, or "languaging" in the tanka produced in this era. 
growing whatever would make the most money and spending it to buy our own food. Now I see Shiraishi had the right idea. Ah, I'm tired, Kichi. Can you bring me a glass of water?"27

In the ninth installment Kichizō sets out for Tanaka's again, listening to his sisters practice their lessons as he leaves. He explains the situation of his father's impending death to Tanaka. Tanaka offers to help cover the medical bills and sends for the doctor to help with the father's final moments. The doctor gives him an injection that makes him feel better for a few days. He pleads for his son to take him outside for the first time in three years to see the landscape. Kichizô reluctantly agrees at his mother's insistence. His father sees how tall the orange trees have grown and longs to walk amongst the coffee trees as well, but Kichizô convinces him not to push his luck and they return inside. That night the father's condition takes a rapid turn for the worse and he does not make it through the night. An ellipsis marks the division between two paragraphs suggesting some time has passed. It is during this unspoken interval that Kichizô and his mother have no alternative but to sell the coffee plantation, and the story concludes with Kichizô bereft. He can only stare in grief at the land they'd worked in vain.

In "Kafé-en o uru" Sugi was attempting to fulfill his own criterion of writing about the immigrant experience. He wrote what may be one of only two texts in modern Japanese literature to mention the greatest political and military crisis in twentieth century Brazil, an event that would have considerable implications for policies of assimilation and repression against the Japanese and other immigrants in the years to come. It also survives as an important reminder that the de facto persecution of Japanese immigrants by federal soldiers had already begun well in advance of Vargas' nationalization schemes or the repercussions from Pearl Harbor that ultimately brought the United States, and later Brazil, into the war.

Despite the adverse conditions the immigrants faced in Brazil throughout the 1930 s, the state of affairs back in Japan offered no palatable alternative. This was the era of "government by assassination," from the May 25 Incident of 1932 that assassinated Prime Minister Inukai Tsuyoshi, to the failed coup attempt on Feb 26 Incident of 1936 that assassinated two former prime ministers and other government officials. Such events were regularly reported on the front pages of the Burajiru Jiho and its fellow publications. Political instability and the conscription of young men like Kichizô to fight and die in Japan's wars provided a powerful incentive for families to emigrate or remain overseas.

5. 5. Serialized in five installments, "Tera Roshya" is a compact first person narrative told from the perspective of an unnamed young man newly arrived in the interior of São Paulo. His employer, Gotô, owns his own plot of land, but never sets foot on it,

27 Sugi Takeo, "Kafé-en o uru," in Dec. 6, 1934 issue of the Burajiru Jihô. 
devoting his small amount of capital to opening a drinking establishment. "I think a little differently than the general run of society," he pronounces by way of explanation. ${ }^{28}$ The narrator offers a severe assessment of culture and economy of the coffee country in which the Japanese are equally complicit in the social ills of drunkenness, domestic abuse, and racism. Sugi further attempts to realize, albeit in a still tentative form, the critique of capital and labor he had polemicized in his first essay several years earlier. Yet what ultimately eclipses the narrator's social analysis is his resignation to the futility of human endeavors against the sheer force of nature in Brazil.

To get a sense of how São Paulo's terra rossa has historically been discussed, we can do no better than look to "The Economic Climatology of the Coffee District of Sao Paulo," written in 1911 by Robert deCourcy Ward's (1867-1931). A professor from Harvard who became the first professor of climatology in the United States, Ward visited Brazil in 1910 and wrote extensively about the climate and conditions in São Paulo State. I quote Ward at length below to convey the sheer scale of Brazilian coffee that dominated the world market:

\begin{abstract}
Brazil stands pre-eminent. She is the colossus. She alone sends out annually threequarters of the world's total coffee crop. No reading of books on coffee can give an adequate idea of the extraordinary position which coffee occupies in the world's commerce. To appreciate this remarkable situation one must travel for hour after hour through the rich coffee plantations of Brazil... Nowhere else in the world does coffee grow more luxuriantly; nowhere else does it find a more congenial climate; nowhere else does it require less care; nowhere else is it more free from enemies. Such a condition of things is unique; it is phenomenal; it irresistibly attracts the traveler. He is drawn to it as he is drawn to visit the world's greatest diamond mine, or steel plant, or ship-yard, or waterfall. It matters little in such a country whether there are (as statistics say) over 15,000 coffee plantations. It matters little whether there are $600,000,000$ or $700,000,000$ coffee trees. It matters little whether the invested capital is $\$ 500,000,000$, or more, or less. It matters little, because figures mean little to most of us, and because the vastness, and extent, and the importance of the coffee industry are here so obvious without any statistics. ${ }^{29}$
\end{abstract}

There are now closer to 220,000 coffee plantations and Brazil instead accounts for about a third of a much more diversified world production, but the country has remained the undisputed leading producer of coffee for the past 150 years. This is thanks to the optimal cultivating conditions enabled by the terra rossa. As Ward elaborates, São Paulo

28 Sugi, “Tera Roshya," Feb. 12, 1937 issue of Burajiru Jihô.

29 Ward, 431. 
[p]roduces the rich red soil that has become famous as the terra rossa and is regarded as the best for coffee culture, being wonderfully fertile, very rich in potash, and containing much iron. The terra rossa lands are the most valuable and keenly desired by coffee planters. They are adapted for the growth of coffee as no other soils seem to be, and the term has become almost synonymous with "a soil suitable for coffee planting." 30

When Ward published his study only a few thousand Japanese were in country and he likely did not encounter them. Still, it would be remiss not to mention his connections to Japanese immigration that were to come. A decade and a half later he became an active proponent of the anti-immigration and eugenics movements in the United States. As Jerome Karabel records, Ward was "one of the founding members of the Immigration Restriction League and a critical congressional witness on behalf of the Immigration Act of 1924. ${ }^{\prime 31}$ His active campaigning against non-white, non-Christian immigration would have a lasting impact in intensifying Japan's mass migration to Brazil even as it provided ammunition to expansionist ideologues such as Tsurumi Yusuke, who considered it a betrayal and confirmation of unwillingness by the white races to allow Japan to peacefully expand through immigration. Meanwhile Brazil's nativist politicians such as Miguel Couto would use similar arguments and the precedents in the Anglophone world to argue for restricting Japanese entry into their country. They used the Constitutionalist Convention of 1934 to reform the immigration law, which drastically reduced the influx of Japanese immigrants from roughly 25,000 per year to around 4,000.

Where Ward waxes eloquent about coffee country, Sugi adopts a different tack. The vignette takes places during the wet summer months when torrential rain has turned the ubiquitous red clay soil into a sea of mud that clings to everything, makes roads nearly impassable, and threatens to ruin the livelihoods of laborers. The cynic Gotô runs a profitable liquor business precisely because he does not depend on the weather or market conditions; hardship for others, in fact, is a boon for him. His ethos of money-making is matched by a blatant disregard for the humanity of his customers. Whenever customers enter the shop, the narrator is instructed to jot down their physical appearance in lieu of names. The young man is particularly embarrassed when a customer comes in and gives his name, as there

30 Ibid., 438.

31 Ward was also instrumental as a member of Harvard's Admissions Committee in 1925-26, according to Karabel's The Chosen, in ensuring the number of Jews was capped at fifteen percent: "Ward appeared as a key witness to the U.S. Congress in favor of the Immigration Ace of 1924. In 1925, he was appointed to the Harvard University Committee on Admission and served on that board until 1931. This committee reduced the size of the freshman class to 1,000 students and arbitrarily reduced the proportion of Hebrew members to 15\%" (110). Yale and Princeton quickly followed suit. 
are only a handful of proper names in his boss' accounts book, the rest constituting crude descriptions by race and appearance. There are English, German, Italians, mulatto and black customers, as well as Japanese, highlighting the polyglot and transient, international character of the boomtown populace in coffee country. Gotô appallingly refers to blacks who enter his shop as "sukebe no kuronbô" (dirty nigger). The narrator, who somewhat reluctantly complies with Gotô's system of accounting, tends to dwell for the most part on the plight of colonos, meaning Japanese immigrants, but clearly the boteco (neighborhood bar) where he works does not depend exclusively on a Japanese clientele.

The young man's cannot help but lament the outsized role of pinga in the countryside. He feels twinges of anger and remorse upon seeing a little girl come into the shop, braving the rain and mud outside to get a drink for her father, whom he names in his head "Nomisuke" or drunkard. He envisions the forms of domestic abuse that arise from the drunken state of many laborers. While he admits he is no Christian or prohibitionist, he sees the social ills caused by pinga in these farming communities. Ironically, this liquid gold is the real profitable commodity, not the red soil that lured them across the world only to dash their dreams.

The true tension in the story goes beyond coffee and alcohol to the fantasy versus reality of the terra rossa. The red soil that turns coffee into black gold-and the only coffee the protagonist is offered in the story is described as mazui, or terrible tastingbecomes an oppressive environment that leads to boredom, depression and for some, alcoholism. In the fifth and final installment the protagonist remarks of a typical day where "every last thing was coated with that red-colored terra rossa. I chewed the tasteless food and stared out the window at the rain." 32 At one point he observes about this vast sea of mud and unending rain: "Somehow I felt in my bones the terrifying force of nature." The story is oddly reminiscent of Abe Kobo's absurdist masterpiece Woman in the Dunes (1966) with its oppressive village life lived at the bottom of sand pits. The precious red soil is similarly transformed into a kind of quicksand that lures so many immigrants to Brazil only to trap and swallow them.

\section{Conclusion}

The imagined community sustained by newspaper and novel is often upheld as a unifying force. As Zelideth Rivas has already noted, "in his book, Burajiru Nikkei koronia bungei gekan (Literature of the Brazilian Nikkei Colônia, Volume 2), Arata Sumu argues that the incorporation of literary columns into Japanese Brazilian newspapers "cause[d] those people who lived their lives in cultural isolation, even if they were farmers, to desire and be compelled to pick up their pens and react to their hunger for communication." ${ }^{33}$ Undoubtedly this is true, and yet even a cursory examination

32 Sugi Takeo, "Tera Roshya" in Feb. 12, 1937 issue of Burajiru Jihô.

33 Rivas, 794. 
of works such as "Kafé-en o uru" and "Tera Roshya" confirms that the immigrants' colonial literature was in a very real sense a literature of hardship and defeat. It therefore stands as a vital testament to the immigrants discovering their shared conditions in their own discursive spaces at arm's length from both nations that variously imposed demands of belonging upon them. 